\title{
TAUFIQ TANASALDY
}

\section{Ethnic identity politics in West Kalimantan}

Local politics in West Kalimantan have assumed a strong ethnic colouring since the end of the New Order. ${ }^{1}$ Some of this has been conflictual, such as the violence in 1997 and 1999. Since the mid-1990s rifts have developed between the two biggest ethnic groups, Dayaks and Malays, over strategic appointments. Tension over political appointments aggravated after the end of the New Order, involving mass mobilization and sometimes violence. However, ethnicity also functions in quite peaceful ways in West Kalimantan, particularly after 2000. Indeed it can be argued that the politics of ethnic 'power-sharing' now widely adopted at the district level has successfully pulled the sting of the violence and prevented a recurrence of the episodes of 1997 and 1999.

This chapter describes the rise of ethnic identity politics in West Kalimantan and asks to what extent they also offer possibilities of civility (as well as the much better known possibilities of violence). It begins by introducing the ethnic politics of Dayaks and Malays prior to the 1998 reform (Reformasi). Ethnic politics here refers mainly to the politics played or led by ethnic elites to secure greater representation in the executive and legislative branches. The first two sections show that the Dayak political resurgence after 1998 was not an instantaneous movement, but a reaction to a history of repression dating back to the colonial period. The third section discusses how the authoritarian New Order regime retarded local politics and hampered discussion of ethnicity, and the unintended effects of this policy. The last sections discuss how the 1998 reform led to a resurgence of ethnic politics.

1 This chapter has benefited from critical comments made by Myrna Eindhoven, the late Isa Sulaiman, Gerry van Klinken, Henk Schulte Northolt, Harold Crouch, Jamie Davidson, Melly G. Tan, Vedi Hadiz, and Claire Conway. I am grateful for informants in West Kalimantan who gave me interviews but who wish to remain anonymous. 


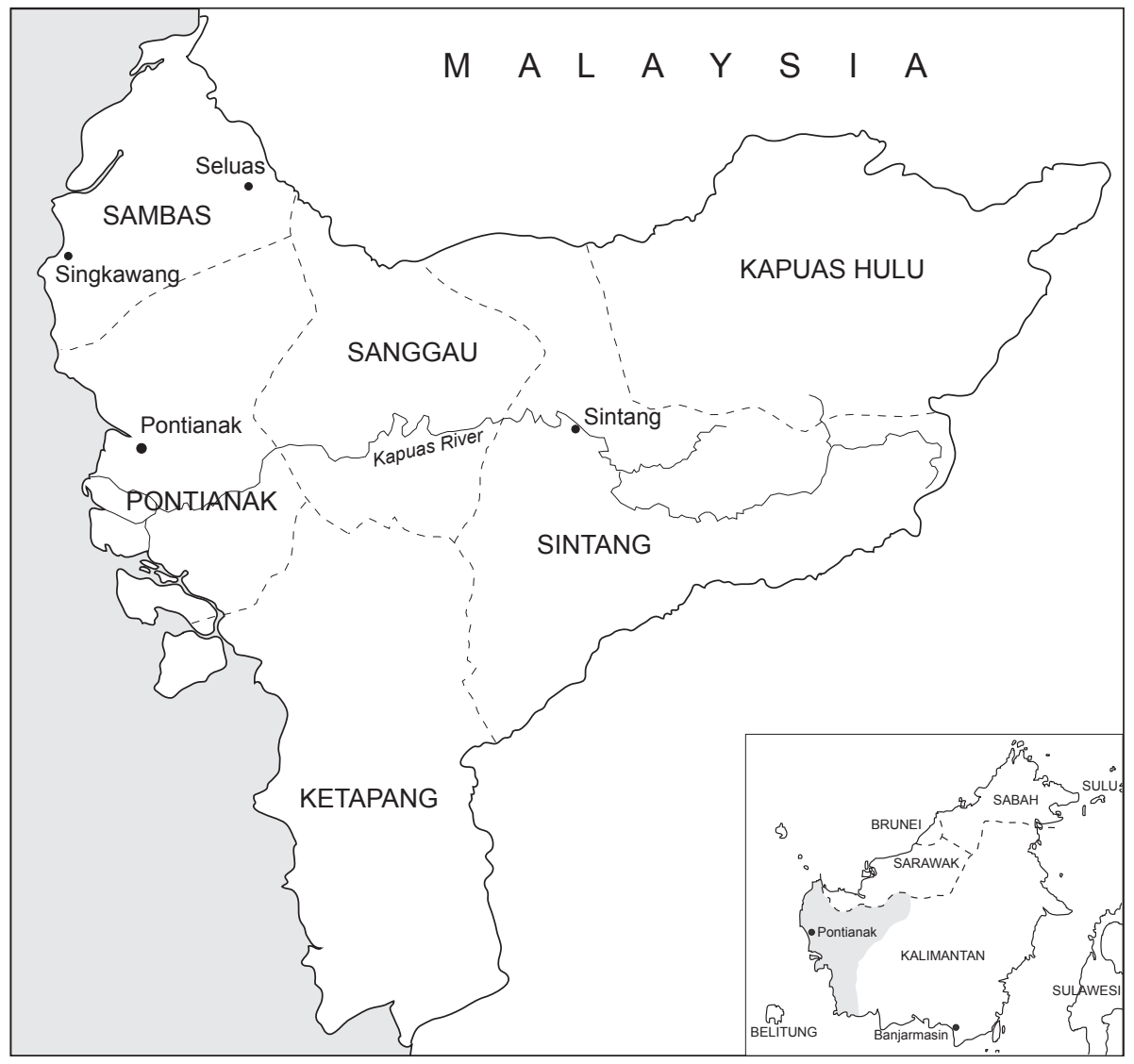

Map 14. West Kalimantan 
Dayak versus Malay: ethnic politics prior to the New Order

\section{Identity formation}

West Kalimantan, like many other provinces in Indonesia, has a diverse ethnic population. Based on the 2000 population census, the two largest ethnic groups are Dayaks and Malays, followed by Javanese, Chinese, Madurese, and Buginese (see Table). This chapter discusses only Dayaks and Malays. The Chinese and Buginese, the other important 'native' ethnic groups with long and significant associations with the province, will not be covered in this chapter, because neither of them have an ethnically consolidated movement in contemporary West Kalimantan. ${ }^{2}$ Javanese and Madurese have only recently begun to arrive in significant numbers, and they also have not engaged in ethnic politics. Madurese come from Madura, an island off the northeast coast of Java, the most densely populated and politically central island in Indonesia.

Ethnic populations in West Kalimantan

\begin{tabular}{lrrr}
\hline Ethnicity & 1930 & 1971 & 2000 \\
\hline Dayaks & $48.9 \%^{*}$ & $41 \%$ & $33.1 \%$ \\
Malays & 28.5 & 39 & 32.4 \\
Javanese & 1.2 & 2 & 10.4 \\
Chinese & 13.5 & 12 & 9.5 \\
Madurese & 0.8 & 0.6 & 5.5 \\
Buginese & 6.6 & 5 & 3.3 \\
\hline
\end{tabular}

(Residual 'others' account for totals just under 100\%.)

Source: Volkstelling 1936; Tjilik Riwut 1979:49; Badan Pusat Statistik Kalimantan Barat 2001:34.

* Combines the categories 'Dayak' and 'unknown' (onbekend), who were mostly Dayaks.

The term 'Dayak' was first employed by Bornean Malays to designate native tribes in Kalimantan. It did not include the nomadic Punan. It was then popularized by European explorers through their writings (Lumholtz 1920:23). The encompassing term Dayak was deficient because it described hundreds of heterogeneous tribal groups. These tribal groups were 'united' only by external forces, such as discriminative policies from Malay sultans and Dutch

2 West Kalimantan Chinese played an important role in the region prior to Indonesian independence (Heidhues 2003; Bingling Yuan 2000). The role of the Buginese was also significant during the Dutch colonial era. Mempawah, one of the more influential sultanates in West Kalimantan, was Buginese. Other important sultanates such as Pontianak and Sambas also had ties with the Mempawah Buginese royals. 
colonialists, as well as through religion.

Unlike the externally imposed term Dayak, the term 'Malay' was already widely in use before the arrival of Europeans in the archipelago. It described the inhabitants of many parts of coastal Sumatra, Kalimantan and the Malayan peninsula. In West Kalimantan, it initially designated people from Sumatra and the Malayan peninsula who came to West Kalimantan for trade and to spread their religion. Later, the term was expanded to include those Dayaks who had converted to Islam. ${ }^{3}$

Dayaks routinely experienced discrimination under the Malay sultanates and Dutch colonialism. In most sultanates, Dayaks did not enjoy the same rights as the majority Malays, and were not considered citizens (anak negeri). Dayaks were not allowed to work under the sultanates. They also suffered social vilification by Malays, which prevented them from participating in social activities beyond their own group, including education. As a result of these obstacles, Dayaks in West Kalimantan were entirely absent from political movements prior to independence. ${ }^{4}$

\section{The rise and fall of Dayak politics}

This situation started to change after the end of World War II. The Allied government led by NICA (the Netherlands Indies Civil Administration) established a Dayak Affairs Office in early 1946. It carried out a series of unprecedented reform initiatives for Dayak emancipation, and secured unconditional agreement from the revived sultanates to abandon discriminatory practices against Dayaks. ${ }^{5}$ NICA pushed for higher education for Dayaks, facilitated their entry into the bureaucracy, and later the local parliaments. ${ }^{4}$ These pioneering policies were of psychological importance to Dayaks. For the first time they were sitting in equal positions with Malay and Sultanate representatives in the government.

Another important actor in Dayak political emancipation was the Persatuan Dayak (PD, Dayak Unity Party), which was established in 1945. PD performed well in the elections in 1955 and 1958 when it won a significant number of seats in both provincial and district parliaments. A Dayak was appointed governor, and four became district heads (bupati). Some assumed positions as members of governing councils (Dewan Pemerintah Daerah,

3 Dayaks treated Dayaks who converted to Islam, also known as Senganan, as Malays. This was a consequence of the Senganan's renouncing their 'inferior' Dayak identities. Senganan would usually resettle in Malay villages, assume new names, adopt a Malay way of life, and claim to be Malay (V. King 1985:57-9; Tjilik Riwut 1993:191; Fridolin Ukur 1971:183).

$4 \quad$ This was not the case in Central Kalimantan. See Van Klinken 2004 and Miles 1976.

5 Kantoor voor Dajaksche Zaken, Pontianak, Notulen Vergadering di Sanggau pada antara Dayak dan Landschap, signed by Oevaang Oeray and assistant resident, 10-10-1946, pp. 4. 
DPD, and later Badan Pemerintah Harian, BPH), and others took on leadership positions in local parliaments. ${ }^{6}$

As a result of national policy aimed at curbing regional political parties as well as internal rivalries within the party, by the early 1960s the PD had split into two factions. The biggest, led by the Dayak governor Oevaang Oeray and supported by most Dayak civil servants, joined the left-leaning national party Partindo. The other, led by Palaunsoeka and supported mainly by Catholic teachers and church personnel, joined the Catholic Party (Partai Katolik). This party was generally excluded from parliamentary politics in West Kalimantan from the 1960s until the collapse of the Sukarno government.

Dayak politics under a leftist Partindo suffered a significant setback after the 'communist' coup attempt on 1 October 1965. In mid-1965, under the initiative of the local military commander, West Kalimantan's Partindo branch merged into Ikatan Pendukung Kemerdekaan Indonesia (IPKI, League of Supporters of Indonesian Independence), here a small nationalist party dominated by Malays. After the merger, a clash of ethnic interests occurred within the party. The original Malay members felt threatened and were disappointed with the new leadership structure which included many Dayak figures. This culminated in 1968 when Tan Husni, a Malay and chairman of IPKI, expelled all ex-Partindo members from IPKI. ${ }^{7}$ Although later annulled by party headquarters, the expulsion left a scar on relations between the two ethnic groups. It was one reason why many Dayak leaders were persuaded to join Golkar in the emerging New Order. Golkar had closely followed the internal friction within IPKI and wished to cultivate Dayak support. Its efforts however, were initially unsuccessful. ${ }^{8}$ The patience of the regime ran out in 1971 as the general election approached. In January those Dayak leaders who had refused to join Golkar and who had links with the Chinese association Badan Permusyawaratan Kewarganegaraan Indonesia (Baperki, Consultative Body for Indonesian Citizenship) were arrested. ${ }^{9}$ Oevaang Oeray, the former governor, was transferred to Jakarta at the end of March 1971. Without Oeray's presence, some ex-Partindo Dayak leaders yielded to the pressure to join Golkar a month later. ${ }^{10}$ In the 1971 election, Golkar won

6 IPKI, Jakarta, Partai IP-KI Kalbar, IPKI document signed by Achmad Sukarmadidjaja, H. Djilis Tahir, 10-2-1971, pp. 6.

7 Davidson 2002:93-101; L.H. Kadir 1993:304-8; H.M. Baroamas Jabang Balunus n.d.

8 IPKI, Jakarta, Partai IP-KI Kalbar, IPKI document signed by Achmad Sukarmadidjaja, H. Djilis Tahir, 10-2-1971, pp. 6.

9 Dokumen Pemerintah Indonesia, Singkawang, Surat Perintah untuk menangkap/menahan sementara, issued by Laksus Pangkopkamtibda KB, Team Pemeriksa Kodim 1202 Sambas, 14-11971.

10 Golkar, Pontianak, Pernyataan bergabung dengan Sekber Golkar, signed by A. Djelani, P. Anjiem, I. Kaping, A. Sawa, J.M. Linggie, 17-4-1971, pp. 1. 
21 seats in the provincial parliament (Dewan Perwakilan Rakyat Daerah, DPRD) or more than $66 \%$ of the total, whereas IPKI and Partai Katolik, the two supposed Dayak strongholds, won only two seats each.

\section{Malay politics: a response}

Malay politics differed from Dayak politics in many ways. The Malay outlook was integrated with national politics much earlier than that of Dayaks. Consequently, after independence, Malay politics were more nationalist, pro unitary state, and therefore Jakarta oriented; while the less exposed Dayaks formed their own local party and supported Dutch federalist policies. Most Malay bureaucrats did not at first consider the rise of Dayaks after 1945 a threat. However, ethnic tensions grew when angry Dayaks victimized some Malay elites in the Landak region, and created chaos in the provincial capital. More tension was prevented after Malay leaders in Pontianak backed down from their earlier demand to arrest the Dayak war leaders, fearing it could incite revenge from their followers (Hassan H. Basry 1961:69-70). From 1945 until the dissolution of a pro-Dutch administration in West Kalimantan in 1950, Malay and Dayak elites were at odds because of their different political outlook. Malays and Dayaks were at the brink of open conflict at the end of 1950 in the interior district of Kapuas Hulu. The Dayak rise in the bureaucracy after their successes in the 1955 and 1958 elections also did not go without reaction. In 1962 for example, non-Dayaks accused Oevaang Oeray of practising ethnic preference in recruitment and promotion of civil servants. ${ }^{11}$ Allegations that he was creating ethnic fissures led in early 1965 to demands that he step down. ${ }^{12}$

\section{New Order authoritarianism}

\section{The marginalization of local politics}

The New Order never wanted to have strong local leadership, fearing it would lead to challenges to national leadership and in the worst case to separatism. One way to prevent this was to appoint 'national' civil servants, often from Jakarta, at the local level. Frequent rotation of key officials such as military

11 Dokumen Pemerintah Indonesia, Pontianak, Pokok: Permohonan pindah Sdr. Mochtarroeddin, pedjabat Wedana Putussibau ke Kantor Gubernur Kepala Daerah Kalimantan Barat, letter signed by Oevaang Oeray, 12-1-1962.

12 Surat Resolusi untuk meretul Gubernur Oevaang Oeray, signed by Abi Hurairah Fattah (PNI), Chris F. Hetharia (Parkindo), PF Soedjimin (PK), Ismail Hamzah (Angkatan 45), Pontianak, 8-3-1965, pp. 2. 
commanders was intended to prevent them from cementing close ties with local political forces. In 1999, the majority of local department and bureau heads in West Kalimantan were non-locals, although Malays held some positions and Dayaks even fewer. ${ }^{13}$ Another way was to centralize the recruitment of future local elites. Together with similar institutes elsewhere in Indonesia, the prestigious local civil servant training institute (Akademi Pemerintahan Dalam Negeri, APDN) in Pontianak was closed and replaced by a single institute (Sekolah Tinggi Pemerintahan Dalam Negeri, STPDN) in Bandung, near Jakarta, in 1992. Since then, the national institute has accepted only around ten students from West Kalimantan annually, which is much less compared to the 50 students annually, mostly locals, who entered the APDN Pontianak. ${ }^{14}$ At the end of the 1960s and during the early 1970s, graduates from the APDN Pontianak had been fast-tracked to become sub-district heads (camat). Fewer STPDN local graduates meant fewer locals to assume these strategic posts.

In an effort to ensure that national interests were paramount over regional ones, strategic decisions were made in Jakarta, in a top-down fashion. District head elections illustrate this. Usually, the central government pre-selected the district head prior to the selection process. It then closely monitored the whole process from the nomination until the election. The government had the power to intervene at any stage to ensure that its own candidate won.

The regime's policy was accentuated by a strong military presence. This was not unprecedented in West Kalimantan. The province's long border with Malaysia invited military attention. They were the dominant force during 'Confrontation' with Malaysia in the early 1960s, and even more so during the early New Order while they combated what they called a communist insurgency (Davidson and Kammen 2002). At this time the military took over strategic positions formerly assigned to civilians such as governor, district head, and parliamentary chairperson. Before the New Order there was only one military district head (Hercan Yamani of Ketapang). But by 1968, five of the seven district heads and mayors were military officers. Four district DPRD chairs were also given to military officers. ${ }^{15}$ The power of the military was so great that their regional commander undermined the power of the governor. One high-ranking official revealed to me that Soemadi, the governor from 1966-1971 who was also a military officer, was agitated when the military commander bypassed him on several important decisions. Supported by an extensive command and intelligence network from the provincial down to the

13 'Kemerdekaan, penindasan dan tuntutan merdeka', Kalimantan Review 48(1999):5-7.

14 APDN, Pontianak, Meletakkan landasan yang kokoh dalam mengembangkan kiprah organisasi beserta himpunan keputusan hasil Musyawarah I Ikatan Alumni APDN/STPDN se Kalimantan Barat, 1997.

15 Dokumen Pemerintah Indonesia, Pontianak, Laporan Gubernur Kepala Daerah Propinsi Kalimantan Barat dalam sidang terbuka DPRD-GR, Propinsi Kalimantan Barat, 11-3-1968. 
village level, military bureaucrats effectively controlled local politics.

The New Order severely weakened once influential local bureaucrats and political parties. During the period between 1965 and 1971, political parties other than Golkar were demonized, repressed, and separated from their constituents, thus losing their influence. All civil servants, traditionally a source of support for political parties, were required to sever ties with these parties in 1970, prior to the general election. Under these conditions, the other parties fared poorly in the 1971 election, and never recovered. The 1973 national party restructuring caused serious internal friction within the parties, particularly during the general elections in 1977 and 1982. Continuous government interventions further crippled the political parties. For example in 1996-1997, the government effectively orchestrated PDI's West Kalimantan branch to oppose the leadership of the oppositionist Megawati, despite her popularity among party supporters.

\section{Nation building and local culture}

Particularly once the New Order was over, a cultural discourse emerged that blamed the New Order's promotion of a national culture for the degeneration of local culture. Dayaks in the NGO Pancur Kasih, for example, accused the New Order of dismantling their longhouses. Malays held similar convictions over their culture, saying that only Islamic symbols had survived the New Order. ${ }^{165}$ Both cultures had already been in decline long before the New Order. Dayak culture has undergone rapid erosion since the introduction of Islam and Christianity. Indeed, earlier Dayak politicians had in fact asked Dayaks to abandon some 'antiquated' or 'extravagant' traditions in the name of modernity (Davidson 2002:97). Malay culture waned with the declining fortunes of the sultanates, the centre of Malay civilization in the past. The last remnants of the sultanates' administration (swapraja) were abolished prior to the New Order. However, the New Order should also share some of the blame, because it did not try to support those declining cultures, or at least did not prevent them from disappearing altogether. Some New Order cultural policies accelerated the dissolution of local cultures by absorbing them into a national culture.

Local icons that might threaten the country's unity and Jakarta's authority were removed. Sultan's palaces were converted into museums or left to decay. Longhouses, powerful symbols of Dayak communal life and unity, were largely annihilated during the New Order era. The regime claimed they were places of free sex and unhealthy living, fire hazards, reminders of headhunting, and, most importantly, media for communism (Djuweng 1996:7; Roekaarts 1985:15). Many functions attached to the longhouse ceased to exist. 
Communalism and congeniality among Dayaks decreased, oral traditions were forgotten, and arts and performance related to life in the longhouse declined (Djuweng 1996:17, 124; Drake 1982:49-52). Many Dayak youngsters in the city do not speak their own language because they consider Indonesian or Malay to be more prestigious than their own languages. ${ }^{17}$ Dayak cultural performances were portrayed as exotic and primitive. Shifting agriculture was held responsible for forest fires from the 1980s. The regime sponsored Christian missions to convert 'animists'.

Traditional authority was also affected by administrative changes. After 1979, traditional village heads were rapidly replaced by a younger but less respected generation of public servants. Robbed of their traditional authorities, villagers were drawn to modern apparatuses such as the police who were backed by state power, and thus they discarded many of their traditions. Reorganization of village boundaries after 1979 further jeopardized traditional leadership.

Transmigration, the expansion of plantations and logging activities added to the pressures on local cultures. Dayaks, who usually lived in small groups, became a minority in transmigration sites such as Seluas, in Sambas district. ${ }^{18}$ Many inland villages now have Javanese or even Batak names. ${ }^{19}$ Dayak NGO activists said that plantations and logging introduced prostitution and marriages of convenience (kawin kontrak). Locals were pushed to cut down trees in sacred forests for logging companies.

\section{SARA and ethnic politics}

The New Order opposed all discussion on ethnic or other 'sectarian' issues. ${ }^{20}$ The regime feared such issues could lead to social instability or separatism. After 1971 no New Order census referred to ethnic groups. The West Kalimantan government followed instructions closely by not including ethnic information on their employee records. ${ }^{21}$

The regime also exercised strong censorship. The use of the terms 'Dayak'

17 Julipin and Pius 1987. Assimilation toward a more powerful and prestigious culture is often observed. In Norway, for example, the 'inferior' Sami were incorporated into the mainstream Norwegian culture (Eriksen 1993:29).

18 'Masalah kependudukan di Kalimantan', Kalimantan Review 19(1996):12.

19 Some Iban villages were given new names such as Toba, Pulau Manak, and Rantau Prapat by a Batak sub-district head in the early 1980s (Lumenta 2001:113). Javanese names were given to many new villages, and to some villages which previously had Chinese names.

20 Issues to be avoided were summarized in the acronym SARA, 'Suku, Agama, Ras dan Antar-Golongan', meaning Indonesian ethnicity, religion, race (that is, the Chinese) and 'class conflict' (that is, Marxism).

21 However, its provincial human resources department blundered by leaving religious information easily available. In West Kalimantan ethnicity can be easily identified through religion. The 2000 census once more included ethnicity as a category. 
and 'Malay' in local newspapers was rare.22 Much reporting on 'Dayaks' was camouflaged with terms such as isolated (terasing) or inland (pedalaman) groups. In reporting ethnic conflict, the media never disclosed the ethnic background of perpetrators. Its causes were always described as 'not ethnic' but 'common criminal' (for example Akcaya 16-11-1979). Ethnic-oriented NGOs were kept under tight control. They themselves often exercised self-censorship so they could continue their activities. Ethnic organizations established before the 1997 conflict, such as Pancur Kasih, refrained from mentioning the ethnic groups with which they were working.

However, the SARA-sensitivity of the regime did not prevent the eruption of several ethnic conflicts, notably between Dayaks and Madurese. ${ }^{23}$ All these violent conflicts started with small altercations in which a Dayak was victimized, which triggered a strong Dayak reprisal. Government officials as well as social experts who analysed these events, particularly after 1997, often agreed with Dayaks that Madurese had been culturally insensitive and callous toward their surroundings.

Most ethnic violence involving Dayaks and Madurese in West Kalimantan does not appear to have been politically motivated. However, political elites did try afterwards to take advantage of them, particularly those that evolved into widespread violence such as in 1997 and 1999. Their role only appeared in the middle to later stages, after significant casualties had fallen. One of their motivations to become 'involved' was to secure ethnic concessions. In the conflict in 1996-1997 for example, Dayaks through their customary councils (to be discussed below) were merely intensifying long-standing demands for political positions for themselves.

Open ethnic politics were certainly not entertained during the New Order. However, they continued at a more subtle level after 1966 within West Kalimantan's bureaucracy. These were usually between Dayaks and Malays but also, for example, between coastal (Sambas) and inland Malays. In the early 1980s, Dayak politicians in Sanggau district (unsuccessfully) demanded several top positions. In 1982 they threatened to sabotage a Golkar victory in the district election. ${ }^{24}$ In June 1993, several months after a successful national Dayak seminar, three Dayak politicians wrote a letter to the governor and all other related departments including the president, among others demand-

22 Between 1980-1990, the local newspaper Akcaya published only six articles on the Dayak (Davidson 2002:261).

23 'Sejarah perang suku di Kalbar', Kalimantan Review 50(1999):10; Davidson 2002. The only one of numerous events that did not involve the Madurese as the 'victim' was the conflict in 1967, when Dayaks expelled the Chinese population from the interior of the Bengkayang and Landak regions. Davidson and Kammen (2002) claim that this episode was driven by the military.

24 Golkar, Sanggau, Laporan khusus; Kelompok 11 di Sanggau, signed by Oteng Sukarna, 28-4-1981, pp. 6. [Introductory letter signed by Djalaluddin Latarissa.] 
ing at least three Dayak district heads. ${ }^{25}$ This demand was probably the entrée for the two most important cases of New Order ethnic politics in West Kalimantan: the district head elections in Sintang (1994) and in Kapuas Hulu (1995).

\section{Sintang district head elections 1994}

L.H. Kadir, a Catholic Dayak bureaucrat, was the government-favoured candidate in the Sintang district head election in 1994 (Tammar Abdulsalam 1997:157). The other 'accompanying' candidates (calon pendamping) were Abdillah Kamarullah and Abdul Hadi Karsoem, both Malay bureaucrats in Sintang district. Kadir's appointment seemed guaranteed because Golkar and the military faction occupied almost $80 \%$ of the seats. On top of that, Kadir also received support from other parties, particularly PDI which had four Dayak members. But the election in February 1994 turned out to be different from the usual scenario. Kamarullah won the election with 21 votes, while Kadir only got 16 votes, and Karsoem got one vote. ${ }^{26}$ Malays welcomed Kamarullah's victory because two previous district heads had been Christians. For the Dayaks, Kadir's failure heightened their conviction that there had been concerted efforts to marginalize Dayaks in the bureaucracy. A Dayak head of the Golkar faction calculated that the defeat had been caused by the defection of almost half the Golkar members. I was told he was also convinced that the defectors were Muslim and non-Dayak (see also Davidson 2002:268). The fact that the regime immediately applauded the election result angered Dayaks (Kompas 12-2-1994, 2-3-1994; Akcaya 1-3-1994, 3-3-1994). It was highly unusual for the regime to celebrate the defeat of its own candidate. Dayak elites and commoners tried to reverse the result by sending delegations to Jakarta (Kompas 1-3-1994). Demonstrations were staged in Sintang and Pontianak (Tammar Abdulsalam 1997:161-2), and some Dayak politicians even threatened to quit Golkar if Kadir was not installed (Akcaya 1-3-1994; Kompas 2-3-1994). Golkar responded by sending a delegation to investigate matters (Akcaya 2-3-1994), but the government signalled it would not reverse the decision.

25 The letter dated 21 June 1993 was signed by G.P. Djaoeng, Rachmad Sahuddin, and A.R. Mecer, influential Dayaks. Djaoeng was the first Dayak district head elected in 1958. Sahuddin was involved in the establishment of district and provincial customary councils. Mecer was the 'brain' and one of the founding members of Pancur Kasih Foundation, a respected Dayak NGO. All were members of Golkar.

26 Kadir himself was not present during the election. One source mentioned to me that Kadir was not interested in the position because of family considerations. His lack of interest might have given incentives for the manoeuvres not to elect him. 
After a delay to allow tensions to ease, Kamarullah was sworn in as Sintang district head on 5 April 1994 (Davidson 2002:268). The inauguration did not pass without incident. Two Dayak members of parliament, representing Golkar and PDI, interrupted the inauguration. In Sengah Temila, hundreds of kilometres from Sintang, hundreds of Dayaks vented their anger by blocking the main road between Ngabang and Sanggau and smashing windows of passing cars (Tammar Abdulsalam 1997:163; Davidson 2002:268). This event was the first open political opposition from the Dayaks. It showed that even an authoritarian regime could be 'challenged', and it set a precedent of overt ethnic politics for the next district head elections. All this helped to set the stage for a more severe conflict in 1996-1997.

\section{The Kapuas Hulu district head election in 1995}

The election of the district head in Kapuas Hulu in 1995 can be seen as a continuation of the unfinished Kadir saga. In order to assuage the upset Dayaks, the governor reserved this post for the middle-ranked bureaucrat Jacobus Layang. He was not the most senior Dayak bureaucrat, but he was certainly one of just a few to have climbed to the middle ranks. ${ }^{27}$ His appointment benefited from his close relations with the military, as well as from his appointment as chairman of the newly established Majelis Adat Dayak (MAD, Dayak Customary Council). ${ }^{28}$ Taking a lesson from Sintang, the governor had taken serious steps to prevent an unexpected result. Tammar Abdulsalam, Deputy Governor II who was responsible for elections in Sintang and Kapuas Hulu, was temporarily relieved from his duties. The main reason was his failure to deliver Kadir as Sintang district head the previous year. He was replaced by a confidant of the governor, the incumbent district head of Kapuas Hulu. To eliminate ethnic complications in the election, the Minister of Internal Affairs dropped two Malay candidates from the final list. The remaining three candidates were all Dayaks. ${ }^{29}$ Finally, a senior Dayak politician, Iman Kalis, was dispatched as the governor's 'envoy' to Kapuas Hulu prior to the election to ensure the election of Layang. ${ }^{30}$ The governor's precautions against a Malay

27 The only two Dayaks with higher provincial positions at that time were L.H. Kadir and J. Sotorman. The governor was not comfortable with 'weak' Sotorman, but at the same time he could not offer the position to Kadir, who had earlier been rejected in Sintang.

28 His relations with the military appeared to be more important than his role in the MAD, which had no political significance and little influence within the Dayak community.

29 The names of five candidates were sent to the Minister of Interior for final approval, two Malays and three Dayaks. Knowing that the government would give the position to a Dayak, these two Malay candidates claimed they were 'Dayak Islam' during the election process (Tammar Abdulsalam 1997:165).

30 This information comes from various interviews. 
'scheme' proved to be wise. After the failure to get any of their candidates on the final list, the Malay politicians were manoeuvring to elect the 'best' Dayak district head who could serve their interests. They chose the terminally ill St Kupon. They believed his poor health would not permit him to serve for long, and his Malay deputy would soon take over. ${ }^{31}$ They planned a narrow win for Layang one day before the election. With this strategy Kupon could win the election with only a small swing in the voting, and the schemers could avoid being blamed for insubordination because in an election small vote swings are always possible. Further, they encouraged sub-ethnic divisions between the Dayak members of parliament. Sensing the manoeuvres, Iman Kalis, the envoy, objected to the marginal winning strategy advanced by the DPRD. He insisted that Layang should have a decisive vote of 18 , while Kupon would have only one vote. He also worked behind the scenes to 'unify' the Dayak vote behind Layang. Even after all these efforts Layang won by only a narrow margin, eleven votes to eight votes for Kupon. Thus increasingly confident ethnic challengers were beginning to threaten the central government's ability to appease this or that ethnic faction by manipulating parliamentary 'votes'. The next phase would be to go public.

\section{Reform and the reinvention of ethnic identity}

The politicization of ethnicity in West Kalimantan has a long history. It has been practised by the underdog Dayaks rather than the more powerful Malays. Like the Dayak elites, ordinary Dayaks also felt the deprivation and marginalization. The government had converted ancestral forests and lands into transmigration, plantation, and logging sites with the promise that they would benefit local Dayaks. However, many of these projects in fact worsened their living standards. As the problems increased, silent discontent was slowly transformed into more active protests. In the 1990s groups of villagers went to the local legislative assembly to demand justice in the form of compensation. As the government ignored these demands, peaceful engagements transformed into more violent protests manifested in the burning of plantations, confiscation, and blockades of access to plantations (Davidson 2002:264-6). Thus, Dayak elites, enlightened NGO activists, and ordinary Dayaks began to converge from the mid-1990s into an important political force and accelerated their political momentum. The district head elections of 1994 and 1995 indirectly strengthened the Dayak bonds vis-à-vis other groups. As the movements gathered momentum, Dayaks grew more prepared to act. The events of 1996-1997 became the turning point. It became

31 One high ranking official of Malay origin described the scheme to me as a wicked plot or rencana busuk. 
the most violent conflict between Dayaks and Madurese in the history of West Kalimantan (Davidson 2003:71-6; Human Rights Watch 1997). After a long period of distress and marginalization, this conflict could be seen as a radical self-assertion by the Dayaks, in this case directed against Madurese immigrants (Davidson 2003:320-1).

The Reformasi of 1998 released a flood of contestation that had previously been taboo, also in the area of centre-region relations and ethnicity. Demands for greater autonomy, or even independence, were growing. ${ }^{32}$ Other issues were the subdivision of existing districts (pemekaran) and the rights of native sons (putra daerah), both of which became vehicles for competition between the two main ethnic groups in West Kalimantan (Bamba 2002:6-7).

\section{Peaceful ethnic politics after the New Order}

Contrary to the exclusively violent images created by the widely publicized conflicts of 1997 and 1999, ethnic politics have become widespread and 'normal' in West Kalimantan, but also by and large peaceful. Indeed, the ethnic compromises reached in these politics are designed to short-circuit the recurrence of violent conflicts. The following sections describe the dynamics of these peaceful ethnic politics.

\section{The creation of new 'ethnic' districts}

The idea of subdividing districts in West Kalimantan was first discussed at the end of the 1950s, but not implemented as national politics took a centralizing, authoritarian turn under Guided Democracy. The issue resurfaced in the early 1990s. In 1996 the governor proposed some divisions (Akcaya 283-1996), but district heads and district legislatures cautiously preferred to await a firm decision from the top. However, within a year after the end of the New Order two new districts, Bengkayang and Landak, were carved out from the districts of Sambas and Pontianak. Despite government denials, ethnicity became a major consideration in this pemekaran process. Landak and Bengkayang were Dayak districts. In Landak, the Dayak population was 79\% while Malays made up only $9.7 \%$. The Dayak population in Bengkayang was $52.4 \%$, while the Malay formed a minority of $18.7 \%$ (based on the Indonesian Census 2000). After the division, their respective parent districts, Sambas and Pontianak, became overwhelmingly Malay. The government drew the boundaries of the new districts according to ethnic lines. Thus the majority Dayak sub-districts of Mandor, Menjalin and Mempawah Hulu, which were originally to have remained with Pontianak district, were reassigned 
to Landak. ${ }^{33}$ The government also fast-tracked the subdivisions in conflictprone areas. Bengkayang, for example, was established earlier than the better-prepared but tranquil Singkawang. The formation of Kubu district (out of Pontianak district), which was proposed together with the formation Landak district but which has experienced no conflict, were delayed. The district subdivision in these cases are mainly about power sharing and gaining access to the bureaucracy. It was a conscious decision by the government to subdivide districts as a result of which Dayaks could have their own areas to govern. The aim was to prevent the recurrence of violent ethnic conflict that had happened in 1997 and 1999. This has so far been proven to be successful as the former hot-spots Landak and Bengkayang have been peaceful.

\section{The election of the Sanggau district head}

Under the New Order, district head elections were tightly controlled, and their results were usually predetermined before the elections. After 1998 the central government ceded most of its control to the local parliament (DPRD) (Malley 2003:109). This new arrangement was first tested during district head elections in Sanggau and then in the districts in Pontianak.

Sanggau's election process started in early 1998, still under the New Order. As usual, it proceeded under the strong influence of the governor, who favoured the head of his social political bureau (Sospol), Soemitro, for the job. But previous experience had taught the locals that ethnic pressure could swing the odds in favour of their preferred candidates. Malays had at least two main candidates, Tahir Herita and Setiman H. Sudin. Until the end of the New Order, Sanggau (like Sambas and Pontianak Municipality) had always been reserved for a military officer. This led some Malays at first to rally behind Tahir Herita, who had a military background. When Herita failed to make the shortlist, many switched their support to Sudin. The Dayak candidates were Donatus Djaman, Benedictus Ayub and Mickael Andjioe. For the same reason, most Dayaks rallied behind the military Andjioe. Their strong performance in the ethnic conflict of early 1997 had given Dayaks an enviable bargaining position. Dayaks had also started bargaining through the customary association MAD. Malays showed no signs of ethnic 'awakening' until the end of 1999. Thus the government thought it would be better to make some concessions to soothe the Dayaks.

Unable to diffuse the Dayaks' support for Andjioe, the government eventually gave in. He made it onto the list of five candidates to be sent to the Interior Minister only at the last minute. Still, Andjioe was pressed to with-

33 Akcaya 27-6-1997, 3-6-1998. Based on 2000 population census, those three sub-districts have between $70-90 \%$ Dayak population, and less than $7 \%$ of Malays. 
draw from the competition some days before the May 1998 riots broke out in Jakarta. But President Suharto's resignation in May 1998 had an immediate effect on the election process. The Dayak customary council which had been working hard for Andjioe's nomination stepped up the pressure. On 4 June 1998, the Sanggau DPRD wrote a letter to the governor and the interior minister suggesting that the 'old system' in the election was no longer proper in the era of reform. The 'people' of Sanggau had rejected Soemitro's nomination, the letter went on, and wanted Andjioe to retract his withdrawal.

Realizing the opportunities presented by the reform, Malay leaders who had been disappointed with the earlier developments were once more drawn into the process. Two days after the DPRD issued the letter, Malay leaders asked the DPRD to remain 'neutral' and not be influenced either by (Dayak) 'masses' or by Jakarta's demands. They wanted the DPRD to consider only three candidates in the package who in their view had demonstrated no 'complications' during the process: Donatus Djaman, Benedictus Ayub, and Setiman H. Sudin. They also expressed their respect for Andjioe's decision to withdraw from the competition (Akcaya 8-6-1998). Their requests were astutely devised to block the possibility of Andjioe's return to nomination, as well as to downplay the Dayak demonstrations.

However, the new government in Jakarta was responsive to the more forceful lobby and finally conceded to the Dayak demand. The Tanjungpura regional military commander retracted support for Soemitro, and gave his approval for Andjioe in June 1998. Four candidates were resubmitted to the Interior Minister in September 1998: Mickael Andjioe, Benedictus Ayub, Donatus Djaman, and Setiman H. Sudin. Djaman, an influential Dayak bureaucrat who was also the head of local Dayak Customary Council, was eventually dropped from the final list of three. The government probably feared that with influential Djaman in the race, the Dayak votes would be split, endangering Andjioe's chances. Andjioe won the election in early November 1998 with 29 votes, against Sudin's 12, and Ayub's 4 votes. At the end of the month, Andjioe was sworn in as the second Dayak district head of Sanggau, after more than 30 years.

District head elections after 1999 have been largely peaceful, mostly because of conscious power-sharing between Malays and Dayaks. ${ }^{34}$ Both ethnic groups had reached an understanding of their respective ethnic domains. In the district with one dominant ethnic group, the district head and the deputy head are both to be from that ethnic group. This has been the case in the Dayak Bengkayang and Landak districts, and in the Malay Sambas and

34 There were some protests after the district head election in Kapuas Hulu (2000) and in Sanggau (2003). These were mostly related to intra-ethnic conflict, and therefore not amenable to inter-ethnic power sharing. 
Pontianak districts. In districts with a mixed ethnicity, such as in Ketapang and Kapuas Hulu, mixed leadership is to be expected.

\section{Regional representation}

Another arena for ethnic competition has been the selection of Regional Representatives to the National Assembly (Majelis Permusyawaratan Rakyat, MPR). This is the country's supreme legislative body, and thus very prestigious. West Kalimantan was allocated five Regional Representative (Utusan Daerah) seats in 1999.35 Understanding the possible ethnic tensions in the selection process, provincial DPRD members agreed to informally have the seats divided among the Dayaks, Malays, and Chinese according to a 2-2-1 formula: two for Dayaks and Malays, and one for the Chinese. However, when voting took place on 4 October 1999 the results did not match the formula. DPRD members needed to select five persons from more than 40 candidates. The Dayak vote was divided among four serious candidates. The results of the voting were Oesman Sapta Odang (34), Zainuddin Isman (32), Budiono Tan (29), Ikot Rinding (29), Chairil Effendi (26). This left Dayaks with only one representative, Ikot Rinding. ${ }^{36}$ Feeling cheated, Dayak crowds waiting outside the building became enraged. Under this pressure, the DPRD members decided to annul the letter they had just signed, and promised to reconsider the election (Kompas 5-10-1999). The DPRD was committed to have two Dayaks, Ikot Rinding and Barnabas Simin. The Dayaks kept up the pressure until some time in November 1999, yet the DPRD failed to reconvene because of the lack of a quorum.

Safety considerations may have kept members from attending, but more likely the members, particularly Malays, were less than interested in giving in to the hardball game Dayaks had been playing since 1997. Most of those who prevented a decision by absenting themselves from the relevant DPRD meetings were from Islamic parties. Their confidence in going against the Dayak may have been the result of growing support from Malays. The latter had gained a tremendous boost of confidence and symbolic strength after their own conflicts with the Madurese early in 1999 (Davidson 2003:320). This had proven that Malays matched the physical prowess of the 'war-like' Dayaks. ${ }^{37}$ The conflict had so markedly improved the Malay bargaining position in the new circumstances that it had reached parity with Dayaks. A new ethnic

35 Dayaks of Kalimantan were given one seat for Minority Representative.

36 'Politik reaktif di negeri dongeng', Kalimantan Review 51(1999):34.

37 The conflict itself was no less cruel than previous conflicts involving the Dayaks. Mutilation and cannibalism, although not part of Malay culture, were widespread during the conflict. In terms of ethnic cleansing, the Malay-led conflict achieved more than previous conflicts led by the Dayaks. Most of Sambas remained free of Madurese. 
equilibrium had been reached. One Malay group, Aliansi Masyarakat Melayu Kalbar (AMMK, the Alliance of the Malay Community of West Kalimantan), issued a strong statement on 8 June 1999 warning Dayaks (though without naming them) not to turn West Kalimantan into another Ambon. Some days before, some Malays had clashed with Dayaks in front of the provincial DPRD, a scene not seen since independence. To back their stance on the MPR regional representative issue, Malay leaders argued that the original composition had satisfied the ethnic formula, since another member-elect, Zainuddin Isman, was also a Dayak, although Muslim. ${ }^{38}$ In the end, Dayaks did not get the extra representative in Jakarta until the next round in 2004.

Ethnic identities were also being consolidated in less overtly competitive ways. Sanggau Dayaks, for example, inserted Dayak customary law into a 'village regulation' (Perda Kampung) that was passed by the district DPRD. A similar move is currently underway in Landak district. Malays rejuvenated cultural festivals and revived defunct sultanates. Many of these activities were organized or supported by ethnic organizations such as MAD, YKSPK, MABM, to be discussed below.

\section{The role of ethnic institutions}

The history of the Dayak Customary Council (MAD) can be traced to 1985, when a district level council was formed in Pontianak district. A provincial customary council (majelis adat) was established almost ten years later in August $1994 .{ }^{39}$ Jacobus Layang, one of its founders, became its head. ${ }^{40}$ Like other semi-state agencies, MAD's existence was closely linked to the regime. Its founding charter declared that it aimed to help the government relate to customary society (masyarakat adat).

MAD's officials were mostly civil servants. As a state-led organization involved in ethnic affairs, it adopted a cautious public profile. The district councils, established earlier than MAD, mostly 'socialized' government policies to the locals. MAD recorded no activities from the time of its inception until 1997, when the Dayak-Madurese conflict erupted. ${ }^{41}$

38 Zainuddin Isman was a second-generation Muslim born in Kapuas Hulu. Many Dayaks did not see Isman as a Dayak since he never admitted himself as a Dayak nor acted as one ('Kita menuntut keadilan', Kalimantan Review 51(1999):33).

39 The initiative, I was told, came from two well-known Golkar politicians: Rachmad Sahuddin and Ikot Rinding (see also Kalimantan Review 26(1997):22-3).

40 He was regarded as an expert on Dayak customary law. Layang was a visiting lecturer at Tanjungpura State University from 1979-1995. He had written several articles on Dayak customary law, and a book on the Dayak war against the Japanese during the Second World War. Davidson writes that Layang was pushed to form MAD in order to boost his profile as candidate district head of Kapuas Hulu (Davidson 2003:269).

41 MAD, Pontianak, Laporan pertanggungjawaban Majelis Adat Dayak Propinsi Tingkat I Kalimantan Barat Periode 1994-1997, 19-9-1997. 
However, the ethnic conflict of 1996-1997 catapulted MAD into prominence. Caught unprepared and shocked by the extent of the conflict, the government turned to MAD for help. MAD mediated between Dayaks, the government, and the Madurese, and participated in government-sponsored peace meetings (see the details in MAD 1997). Understanding that the government could not dispense with its help, MAD seized the opportunity to bargain for political positions. In February 1997, when the conflict was still flaring, MAD organized a meeting to demand political concessions from the government. In the same month it produced a document claiming that Dayak marginalization was one of the main causes of the conflict, and urging serious efforts to remedy the situation. On other occasions MAD asked openly for several vacant bureaucratic positions to be given to Dayaks. Under such persistent pressures, the governor made some concessions. One of the first was the promotion of Ignatius Lyong to head of the provincial human resources in June 1997. After a few successes under this rather receptive governor, MAD became more aggressive. At its first plenary meeting in September 1997, MAD redefined its objectives by explicitly referring to Dayak interests. It changed its name from a generic Majelis Adat (Customary Council) to today's Majelis Adat Dayak. The name change had been suggested by the governor himself. MAD, together with other organizations such as Persatuan Intelektual Kristen Indonesia (PIKI, Indonesian Association of Christian Intellectuals) successfully lobbied the government for two Dayak district heads, in Sanggau and Pontianak District. ${ }^{2}$ MAD continued to pursue Dayak interests, although it yielded little result after 1999. The once accommodative governor had become more resistant. He had discovered the Majelis Adat Budaya Melayu (MABM, Malay Cultural and Customary Council) as a counterforce to MAD. Also, internal friction began to weaken MAD and tarnished its image among Dayaks.

\section{The Pancur Kasih foundation}

Ethnic politics in the post-New Order period were not confined to elite manoeuvring for district leadership but also involved increased ethnic awareness among ordinary people concerned about their livelihoods. ${ }^{43}$ Much of this awareness raising work was done by the Pancur Kasih foundation in Pontianak, a private NGO initially associated with the Catholic Church.

42 Under its chairman Mian L. Simanjuntak, PIKI was very aggressive in demanding political positions for Dayaks and Christians. He was mysteriously murdered in January 2000. Many Dayaks saw the murder as politically motivated.

43 Many arguments in this section follow closely Davidson's arguments (Davidson 2003:256-67). 
NGOs under the umbrella Pancur Kasih Foundation always opposed MAD's approach. They believed that although MAD's jockeying had opened some opportunities for elite Dayaks, it did not benefit Dayaks in general. Nor had they forgotten that some district level customary councils (Dewan Adat Dayak, DAD) had acted as agents of the New Order to persuade Dayaks to let go their lands and forests (Bamba 2000:41).

Pancur Kasih was formed in April 1981 by several Dayak intellectuals and a pastor. ${ }^{44}$ It was part of a network of Catholic institutions and related NGOs in Jakarta, which provided substantial financial support and also introduced its activists to new ideas and to some concerned foreigners.

Some of the most important NGOs under the Pancur Kasih umbrella are the Credit Union which works in the economic area, the Institut Dayakologi (ID) in the social and cultural area, the Lembaga Bela Benua Talino (LBBT, Institute for Community Legal Resources Empowerment) in indigenous rights, and Pembinaan Pengelolaan Sumber Daya Alam Kemasyarakatan (PPSDAK, Strengthening Community Natural Resource Management) in customary land mapping. These NGOs provide financial guidance and assistance, schools and scholarships, as well as more effective and acceptable agricultural practices. They also give legal advice and have equipped Dayaks with critical thinking to face encroaching forces under the name of 'development'. Whereas MAD has tended to be elitist and aimed only at political positions, these NGOs work at the ground level to assist Dayaks to improve their livelihood. This has earned them Dayak respect and support. In January 1997, a group of Madurese attacked one of the Pancur Kasih buildings and wounded two Dayak women. The attack sparked a deadly Dayak retaliation (Human Rights Watch 1997). The chairman of Pancur Kasih, A.R. Mecer, was appointed as the only Dayak representative for the whole of Kalimantan in the National Assembly MPR in September 1999 (Akcaya 15-9-1999). The organization's influence among the Dayak grassroots was recently proven again when a member of the Institut Dayakologi was elected to the Regional Representative Council (Dewan Perwakilan Daerah, DPD) in Jakarta in 2004.45

The credibility of these NGOs on issues related to Dayaks, environment and conflicts, extends beyond the Dayak community. The government has consulted with the Institut Dayakologi for teaching materials on local culture. When the Provincial Statistical Bureau was fined by the MAD because of 'mistakes' in ethnic classification, the bureau consulted the institute for a

44 Pancur Kasih's formal name was Yayasan Kesejahteraan Sosial Pancur Kasih (YKSPK). In 2001, the foundation was renamed as Union (Perkumpulan) Pancur Kasih.

45 Four DPD members were elected from West Kalimantan, two Malays and two Dayaks. Maria Goreti was a staff member at ID of Pancur Kasih. Though her profile was lower than other Dayak politicians, academics, and priests who also ran as candidates, she won an impressive support, second only to Piet Herman Abik. 
solution. Branches of national NGOs such as the Aliansi Masyarakat Adat Nusantara (AMAN, Alliance of the Indigenous Peoples of the Archipelago) and Wahana Lingkungan Hidup Indonesia (WALHI, Indonesian Forum for Environment) were mainly staffed by individuals linked to Pancur Kasih. Pancur Kasih has consistently focused its work at the grassroots level for almost 20 years. It has refused to get involved in parliamentary and party politics. However, some senior members, including A.R. Mecer, the founding member, were convinced they needed to work within the system to create genuine change. Mecer joined the Christian party Partai Pembela Demokrasi Kasih Bangsa (PPDKB, Defenders of Love the Nation Democratic Party) to compete in the 2004 election in West Kalimantan. The PPDKB quickly established itself in West Kalimantan owing to an extensive Pancur Kasih network. The party failed however to pass the national legal hurdles to participate in the election.

\section{The Malay Cultural and Customary Council (MABM)}

Malays were initially slow to take up the challenge offered by the growing Dayak assertiveness. West Kalimantan history reveals that Malays lacked the incentive to build formal ethnic organizations, since they already enjoyed their status as a 'ruling' ethnic group. Even during the heyday of the Dayak PD and Partindo in the 1950s, Malays remained the majority in the bureaucracy and parliament.

This all changed in April 1997, when Malays established the equivalent of MAD and named it Majelis Adat Budaya Melayu (MABM, Malay Cultural and Customary Council). It grew out of earlier similar associations in Sambas and Ketapang districts. It aimed to represent Malays at the provincial level. Already since the 1990s, the provincial government had had difficulty in directing a request for Malay participation for regional Malay conferences or meetings. MABM also aimed to restore the standard of living and revive the culture of Malays, which had been in decline after the dissolution of the sultanates and had been subsumed under a national New Order culture. ${ }^{46}$ Despite denials from its founders, its birth was closely related to the heightened tension as a result of the ethnic conflict in 1996-1997. Malays needed a 'counter' for the Dayak political movements at that time (Davidson 2003:346). MABM's first few years were spent on consolidation. It set up branches at the district level, and focused on getting acknowledgement from the Malays. It kept a low profile during the period of transition in 1997-1998. ${ }^{47}$ None of its

$46 \quad$ Kalimantan Review 48(1999):28.

47 From information obtained in various interviews it appeared that this restrained attitude irked the governor, who on several occasions, as if to balance the Dayaks' demand, urged MABM to take a more aggressive attitude. 
overt policies posed a direct challenge to the Dayaks. Instead it has tried since its inception to be friendly towards its counterpart. For example, it continued to attend provincial Gawai Dayak festivals and participate in 'reconciliation' forums organized by Dayaks. During the 1998 crisis in West Kalimantan, together with other ethnic associations, MABM appeared repeatedly in the newspapers urging solidarity and unity among the ethnic groups.

Nevertheless, MABM could not prevent tensions between Malays and Dayaks from increasing. MABM started to build Malay Traditional Houses (Rumah Melayu) at the provincial and district levels, and encouraged Malays to wear telok belanga dress at festivals and religious events. MABM personnel lobbied the government to incorporate more Malay symbols such as yellow colour and lancang kuning (a traditional boat) in the government premises, such as at the entrance gate. Later, the very existence of MABM indirectly encouraged resistance to the Dayaks, such as occurred during the clash over the MPR representatives in October 1999 described above. The MABM profile was also raised when fighting broke out between Malays and Madurese in 1999-2000. The main actor in the conflict was the Forum Komunikasi Pemuda Melayu (FKPM, Union of Malay Youth Communication), a youth organization which had consultative relations with MABM. ${ }^{48}$ Although relatively quiet in district elections in 1998 and 1999, MABM has been actively promoting Malay concerns in more recent elections. The MABM in Sanggau issued a 'warning' in the 2003 district head election not to have both a Dayak district head and a Dayak deputy. It suggested a list of Malay candidates for the deputy position, to pair with the Dayak district head candidate. In Landak and Sanggau, MBAM led the challenge to the implementation of Dayak customary law. For MABM, national law should always prevail over customary law, and the latter should apply only to the related ethnic group. To widen its influence, MABM maintained relations with the newly revived Malay sultanates, as well as Islamic organizations such as political parties, forums and universities. The objective was to build a stronger coalition visà-vis the Dayaks.

\section{Concluding remarks}

Throughout the post-independence history of West Kalimantan, except during the New Order, ethnic politics have been identical to Dayak elite politics. Dayaks were the only segment of West Kalimantan who constantly and overtly played on ethnic sentiments. They mostly wanted greater representation in the bureaucracy, citing a long history of marginalization. Malay elites 
were more inclined to avoid mobilization and engage in internal office politics, where they had a better bargaining position. The end of the New Order saw a resurgence of ethnic politics. Dayak elites, who had begun to challenge the regime in the mid-1990s, were the first to seize the opportunity offered by the changes occurring in 1998. By mobilizing the Dayak masses, these elites and some ethnic organizations were able to pressure the government to appoint two Dayak district heads. Malays, threatened by the rise of Dayak politics, belatedly formed an ethnic organization in 1997. After the conflict between Malays and Madurese in 1999, which gave them a tremendous boost, the Malays started to answer the challenges posed by the Dayaks.

After 1999, political dynamics among the Dayaks have changed. The customary councils that had played such an important role in 1997-1999 started to lose their influence. They lost ground because the key positions, especially the district head offices, were now institutionally shared between Malays and Dayaks. They also received less support from the grassroots Dayaks because of their elitist approach. Many Dayaks felt that supporting and cooperating with Dayak NGOs such as those under Pancur Kasih would bring more results to the people rather than supporting the MAD and DAD. Meanwhile, Malays created an effective counter movement. Malay-related organizations started to germinate after 1999. The nature of ethnic politics has also shifted from elitist 'power sharing' to more popular issues which affect a wider audience and address fairer civil service recruitment. The issues of district head elections, which used to be the paramount issues, ceased to dominate the agenda.

Ethnic identity will continue to play an important role in West Kalimantan politics, but in increasingly peaceful ways. The trend since 1999 shows that high ethnic politicization between Dayaks and Malays has not resulted in open ethnic violence. Instead, the ethnic politics now played consciously by both Dayaks and Malays has not only prevented further ethnic violence but is part of a new democratic and civil process in West Kalimantan. 